DOI: $10.2478 /$ lpts-2018-0035

MECHANICAL ENGINEERING

\title{
NUMERICAL STUDY OF FLOW-INDUCED VIBRATIONS OF MULTIPLE FLEXIBLY-MOUNTED CYLINDERS IN TRIANGULAR ARRAY
}

\author{
S. Upnere \\ Riga Technical University and Ventspils University College, \\ 36 Viskalı Str., Riga, LV -1014, LATVIA \\ *Corresponding author: upnere@gmail.com
}

The paper presents the numerical study of vibrating multiple flexiblymounted cylinders in a triangular rod bundle. Behavioural trends of six different clusters of oscillating rods have been analysed. The influence of neighbour cylinders on the central cylinder oscillation characteristics is analysed. Finite volume solver of open source computational fluid dynamics is used to calculate the fluid flow in the channel with the cylinder array. Built-in six degreeof-freedoms solver is utilised to simulate cylinder movement. Oscillating cylinders have two degrees-of-freedom. The obtained results are compared with numerical results available in the literature.

Keywords: cylinder bundle, computational fluid dynamics, flow-induced vibrations, turbulence

\section{INTRODUCTION}

Unscheduled plant shutdowns can cause significant financial losses in the industry or environmental pollution in some specific cases. Therefore, it is important to assess potential problem areas already at the system development stage. The investigation of failure mechanisms has been intensively done to get a better understanding of potentially dangerous processes. Rods or tubes in cross-flow heat exchangers and steam generators or fuel rods of nuclear power plants are subjected to flow-induced vibrations if the oscillation amplitude of the rod exceeds a critical value, failures can occur. These failures include fretting wear between the tubes and the tube supports and fatigue due to cyclical stresses [1]. The possible flow-induced vibration mechanisms are described in [2].

There are many publications about physical and numerical experiments of different aspects of flow-induced vibrations in the case with a single flexible rod or tube 
surrounded by the rigid array, for example, [3]-[6]. Analytical and semiexperimental models are also evolved for this simplest case (for more information see a review of Price [7]).

Multiple flexibly-mounted cylinders in the rod array have been studied less. Experimental investigation of a group of three flexibly mounted tubes in an otherwise fixed array has been done by Andjelić et al. [8]. For this case, experimental results prove the existence of three stability boundaries. The instability phenomenon in a tube bundle where the tube flexibility direction is different from the flow direction is investigated in [9]. The authors found that increasing the flexibility angle results in a decrease in the critical velocity of fluidelastic instability (FEI) (description of FEI see in [11]).

Hassan et al. [10] used a Reynolds-averaged Navier-Stokes (RANS) computational fluid dynamics (CFD) solution utilising an arbitrary Lagrangian-Eulerian formulation with moving boundaries to predict fluid force coefficients and combining the coefficient data with unsteady flow model. They got a very good estimation of the FEI of the in-line square and normal triangle array. Jafari and Dehkordi [12] have numerically obtained the FEI onset for seven types of flexible tube bundles in normal triangular arrangements.

This paper presents a numerical study of the closed-packed rod bundle with pitch-to-diameter ratio $P / d=1.1$, where $P$ is the shortest distance between the cylinders centres and $d$ is the cylinder diameter. The aim of the study is to explore the tendencies of behaviour of flexibly-mounted rods affected by the surrounding rods. CFD-based methods have been used to investigate the groups of multiple flexiblymounted cylinders surrounded by rigid rods. Calculations are done using solvers of open source CFD toolkit OpenFOAM. The obtained results are compared with findings [12]. Groups of vibrating cylinders consist of three to seven items.

\section{METHODOLOGY}

The instability has been numerically predicted by the simulation of the unsteady, incompressible and turbulent water cross-flow through the triangular rod array. The two-dimensional modelling has been done to reduce computational costs. The high-performance computational cluster is used for simulations. Rods are described as circular cylinders with diameter $\mathrm{d}=0.008 \mathrm{~m}$. Physical and mechanical parameters and simulation conditions used in calculations are summarised in Table 1.

Table 1

Simulation Parameters

\begin{tabular}{|l|c|c|}
\hline & Nomenclature & Value \\
\hline Fluid density & & $1000 \mathrm{~kg} / \mathrm{m}^{3}$ \\
\hline Fluid kinematic viscosity & & $1 \mathrm{e}-6 \mathrm{~m}^{2} / \mathrm{s}$ \\
\hline Fluid free-stream velocity & & $0.709 \mathrm{~m} / \mathrm{s}$ \\
\hline Mass of cylinders & & $0.0368 \mathrm{~kg}$ \\
\hline Density of cylinders & & $7800 \mathrm{~kg} / \mathrm{m}^{3}$ \\
\hline Diameter of cylinders & & $0.008 \mathrm{~m}$ \\
\hline Pitch-to-diameter ratio & & 1.1 \\
\hline Turbulence intensity & & $5 \%$ \\
\hline
\end{tabular}


With subscripts, f and s denote variables related to the fluid and the solid domain, respectively.

\subsection{Mathematical Models}

The water flow field in the flow domain, $\mathcal{F}(t)$, is governed by RANS equations for steady-state cases and unsteady RANS (URANS) equations (1)-(2) for timedependent cases.

$$
\begin{aligned}
& \frac{\partial \overline{\boldsymbol{U}}_{j}}{\partial x_{j}}=0 \text { in } \mathcal{F}(t) \text { for } t>0, \\
& {\left[\frac{\partial \overline{\boldsymbol{U}}_{i}}{\partial t}+\overline{\boldsymbol{U}}_{j} \frac{\partial \overline{\boldsymbol{U}}_{i}}{\partial x_{j}}\right]=-\frac{1}{\rho} \frac{\partial \bar{P}}{\partial x_{i}}+v \frac{\partial^{2} \overline{\boldsymbol{U}}_{i}}{\partial x_{j} \partial x_{j}}-\frac{\partial}{\partial x_{j}}\left\{\overline{\boldsymbol{U}}_{\imath} \boldsymbol{U}_{j}\right\} \text { in } \mathcal{F}(t) \text { for } t>0,}
\end{aligned}
$$

where bar denotes averaged values, $\overline{\boldsymbol{U}}$ is average velocity, $\bar{P}$ is average pressure, $v$ is viscosity, $v$ is time. The problem must be supplemented with the initial condition (3) and Dirichlet boundary conditions (4) for velocity, and Neumann boundary conditions (5) for normal stresses.

$$
\begin{aligned}
& \boldsymbol{u}=\boldsymbol{u}_{0} \text { in } \mathcal{F}(t) \text { for } t=0, \\
& \boldsymbol{u}=\boldsymbol{g}_{f} \text { on } \Gamma_{D, f} \text { for } t>0, \\
& \sigma_{f} \cdot \boldsymbol{n}_{f}=\boldsymbol{d}_{f} \text { on } \Gamma_{N, f} \text { for } t>0,
\end{aligned}
$$

where $\sigma_{f}$ is a stress tensor and $\boldsymbol{n}_{f}$ is a normal vector, $\boldsymbol{u}_{\boldsymbol{0}}$ is initial velocity in the domain, $\boldsymbol{g}_{f}$ and $\boldsymbol{d}_{\boldsymbol{f}}$ are corresponding values on the boundary.

Moving cylinders are described with Eqs. (6)-(7), which are valid for small displacements $\boldsymbol{\eta}$. Boundary conditions have been defined in the solid domain, $\mathcal{S}(t)$, with Eqs. (8)-(9).

$$
\begin{aligned}
& \rho_{s} \frac{\partial^{2} \boldsymbol{\eta}}{\partial t^{2}}-\nabla \cdot \sigma_{s}=\boldsymbol{F}_{s} \text { in } \mathcal{S}(t), \\
& \sigma_{s}=\lambda(\nabla \cdot \boldsymbol{\eta}) \boldsymbol{I}+2 \mu \varepsilon, \\
& \boldsymbol{\eta}=\boldsymbol{g}_{s} \text { on } \Gamma_{D, s} \text { for } t>0, \\
& \sigma_{s} \cdot \boldsymbol{n}_{s}=\boldsymbol{d}_{s} \text { on } \Gamma_{N, s} \text { for } t>0,
\end{aligned}
$$


where $\mu$ and $\lambda$ are Lamé constants, $\boldsymbol{I}$ is a second rank unit tensor, $\varepsilon$ is strain tensor, $\boldsymbol{g}_{\boldsymbol{s}}$ and $\boldsymbol{d}_{\boldsymbol{s}}$ are values on the boundary.

On the interface, $\mathcal{J}(t)$, between fluid- and solid-domain kinematic Eq. (10), dynamic Eq. (11) and geometric Eq. (12) coupling conditions have been applied:

$$
\begin{aligned}
& \boldsymbol{u}_{f}=\frac{\partial \boldsymbol{\eta}}{\partial t} \text { on } \mathcal{J}(t), \\
& \sigma_{f} \cdot \boldsymbol{n}_{f}=-\sigma_{s} \cdot \boldsymbol{n}_{s} \text { on } \mathcal{J}(t), \\
& \Omega(t)=\mathcal{F}(t) \cup \mathcal{S}(t) \cup \mathcal{J}(t), \mathcal{F}(t) \cap \mathcal{S}(t)=0
\end{aligned}
$$

The set of Eq. (1), Eq. (2), Eq. (6) and Eqs. (10)-(12) formulates a coupled fluidstructure problem.

\subsection{Numerical Implementation}

Open source CFD toolkit OpenFOAM 2.4.x has been used to solve 2D differential equations of continuity and momentum (see Eqs. (1)-(2)). Reynolds number based on cylinder diameter and freestream velocity $U_{\infty}$ is $5.67 \cdot 10^{3}$. Therefore turbulence should be considered. The following twoequation turbulence models are investigated: standard kepsilon, RNG kepsilon, and realisable kepsilon model, to get the equation system closure.

The numerical procedure is based on a SIMPLE algorithm for steadystate calculations. For coupling the pressure and momentum quantities in transient cases, PIMPLE algorithm [13] is applied. Bounded Gauss linear upwind scheme, which fuses the upwind and linear schemes and is second order, is utilised for calculations. First order implicit, bounded Euler scheme is used for time derivatives.

The equation of motion of the flexibly-mounted cylinder can be written as:

$$
\left(m_{s}+m_{a}\right) \ddot{x}_{\imath}+c \dot{x}_{l}+k x_{i}=\boldsymbol{F}_{f},
$$

where $m_{s}$ is mass of oscillating cylinder, $m_{a}$ is fluid added mass, $c$ is the damping coefficient, $k$ is the stiffness coefficient and $\boldsymbol{F}_{f}$ is the fluid force on the oscillating object. Dot denotes the time derivative of the coordinate $x_{i}, i=1,2$. A fluid dynamic force applied to move the cylinder consists of the damping force due to the fluid, the stiffness force due to the rod displacement and the inertia force due to added fluid mass [14].

Built-in six degree-of-freedom (DoF) OpenFOAM solver is applied. DoF of the oscillating cylinder is reduced to $2 \mathrm{DoF}$; rotations and transition in the z-direction are not allowed. Mesh modifications are performed after each calculation step. Constant Laplace's equation for the motion displacement has been solved to update the position of points: 


$$
\nabla \cdot\left(\gamma \nabla D_{m}\right)=0
$$

where $\gamma$ is a diffusion coefficient. Distance-based diffusivity model is applied. Solver allows defining the ring-shaped area where a mesh cell cannot be shrunk or expanded due to cylinder oscillations. Therefore, the boundary layer cells of the vibrating cylinder are without undergoing deformations.

The stiffness coefficient of the flexibly-mounted neighbour cylinders is larger than the central cylinder to avoid neighbour cylinders collisions. The damping coefficient is set to zero to get maximum amplitude.

\section{COMPUTATIONAL DOMAIN AND ANALYSED CONFIGURATIONS}

\subsection{Computational Domain}

The array contains seven rows of circular cylinders. Based on Weaver and ElKashlan's [15] experimental results of flow-induced vibrations in the tube bundle, it is recommended that six tube rows be used. In the model, each row has three whole cylinders or two whole and two half-cylinders, which provide uniform water flow through the array. Cylinder array consisting of the computational domain and its related parameters are shown in Fig. 1. Grey shaded cylinders labelled "c0" to "c6" can vibrate parallel and perpendicular to the flow direction due to hydrodynamic forces. In the figures below, rigidly fixed rods are filled in white. Two springs have been applied to each oscillating cylinder, one in the vertical and one in the horizontal direction concerning the flow direction. The central moving cylinder is in the fourth row.

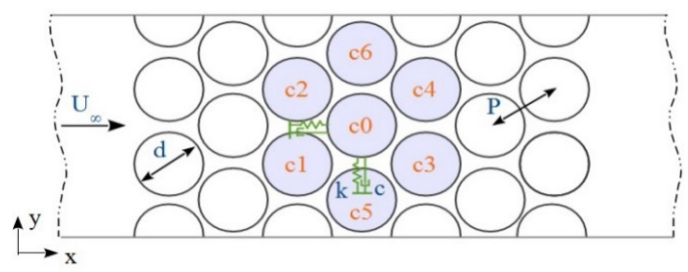

Fig. 1. Cylinders array's part of the computational domain with freestream flow $U_{\infty}$ direction, cylinder pitch $P$, cylinder diameter $d$, stiffness coefficient $k$ and damping coefficient $c$.

Depending on the case, five combinations of flexibly-mounted cylinder clusters are investigated in the present study. Groups of three, five and seven oscillating cylinders are analysed; all cases are presented in Fig. 2.

The total computational domain is $0.416 \mathrm{~m}$ long: $14 \mathrm{~d}$ before and $37 \mathrm{~d}$ after central cylinder "c 0 ". Building the computational mesh, each cylinder perimeter is divided into 600 parts. The cell size in the radial direction is increased with a growth factor of 1.01 till the 20 th cell. 


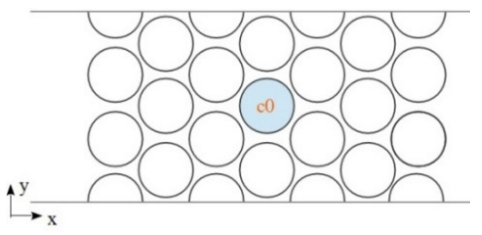

(a) Case I

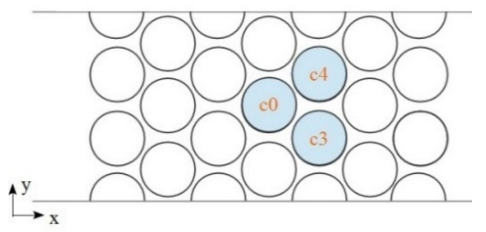

(c) Case III

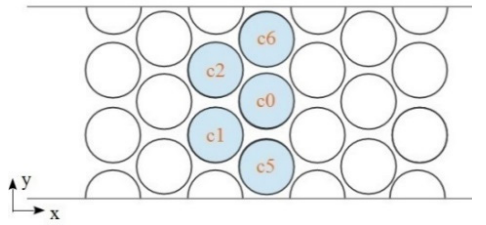

(e) Case V

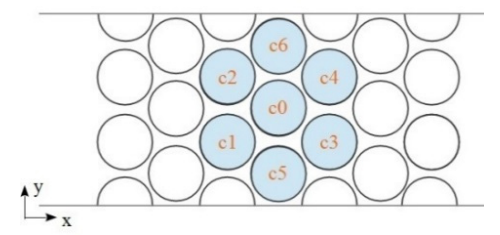

(g) Case VII

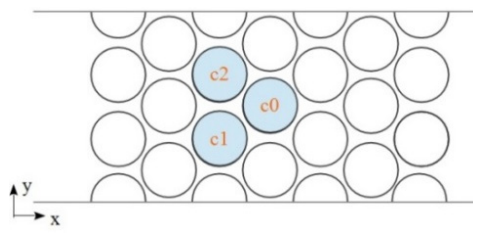

(b) Case II

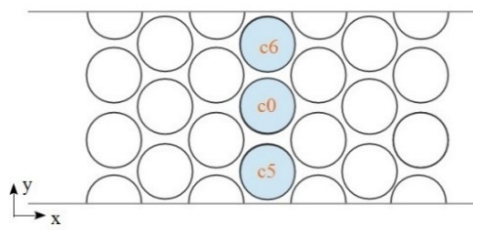

(d) Case IV

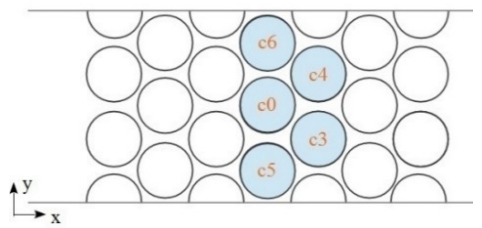

(f) Case VI

Fig. 2. Analysed groups of the oscillating cylinder (grey shaded).

\subsection{Boundary Conditions}

Boundary names in the computational domain are shown in Fig. 3.

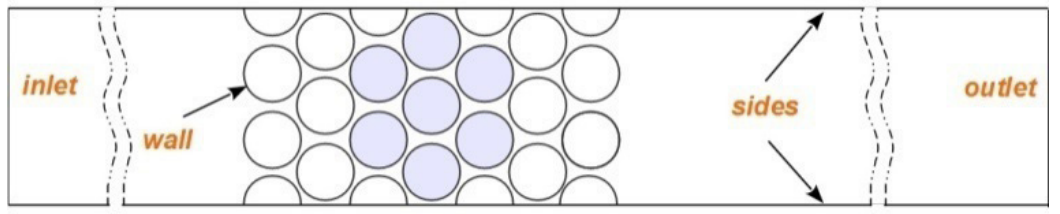

Fig. 3. Boundary conditions of the computational domain.

Constant inlet velocity $U$, the turbulence kinetic energy $k_{t}$ and the rate of dissipation of turbulence energy $\varepsilon_{t}$ are defined at the inlet. Pressure is constant at the outlet. On the rigid cylinder walls, the velocity is set to zero. On the channel sides, the symmetry conditions are applied. The used boundary conditions are summarised in Table 2. 


\begin{tabular}{|l|c|c|}
\hline \multirow{2}{*}{ Name } & \multicolumn{2}{|c|}{ Type } \\
\cline { 2 - 3 } & Dirichlet (fixed value) & von Neumann (zero gradient) \\
\hline Inlet & $U, k_{t}, \varepsilon_{t}$ & $U, k_{t}, \varepsilon_{t}$ \\
\hline Outlet & $p$ & $p, k_{t}, \varepsilon_{t}$ \\
\hline Wall & $U$ & \multicolumn{2}{|c|}{ Symmetry conditions } \\
\hline Sides & \multicolumn{2}{|c|}{} \\
\hline
\end{tabular}

\section{RESULTS AND DISCUSSION}

Numerical calculations are initiated with a series of quasi-steady-state simulations in a 2D domain where all cylinders in the array are static. These tests have been used to select calculation parameters such as boundary conditions, the turbulence models and to investigate the effect of cell size on results. Based on the comparison of the numerically predicted pressure drop with experimental results of the water channel in [16], the model validation has been done. The renormalisation group (RNG) k-epsilon turbulence model is chosen. The steady-state cases are assumed to be converged if residuals are less than $10^{-8}$. The coefficients for the model are given in Table 3. The quasi-steady simulation results are used as initial conditions for the dynamic modelling.

Table 3

RNG k-Epsilon Turbulence Model Coefficients

\begin{tabular}{|c|c|c|c|c|c|c|}
\hline$\beta$ & $\eta_{0}$ & $\sigma_{k}$ & $\sigma_{k}$ & $C_{\mu}$ & $C_{1}$ & $C_{2}$ \\
\hline 0.012 & 4.38 & 0.7194 & 0.7194 & 0.0845 & 1.42 & 1.68 \\
\hline
\end{tabular}

In transient cases, the time step is chosen to correspond to approximately 140 steps per cycle. The suggested resolution of the time step by [10] and [17] is from 35-100 steps per oscillation period; therefore, it can be considered small enough not to affect the simulation results.

The time-dependent simulations have been started with single flexibly-mounted cylinder "c0" in the rigid rod bundle (see in Fig. 2(a)). The major movement of "c0" corresponds to the direction of the freestream flow (see Fig. 4(a)); it fits with experimental measurements of [16], but it disagrees with [12] where cylinders vibrate more in a direction perpendicular to the flow. As follows from Fig. 4, additional flexibly-mounted neighbour cylinders increase the vibration amplitude of the central cylinder "c0".

Three groups of three flexible cylinders (Case II, Case III and Case IV) and two groups of five oscillating cylinders (Case V, Case VI) in the rigid array are simulated. The influence of free to vibrate neighbour cylinders in transverse direction on the central cylinder oscillation amplitude is smaller comparing to upstream and downstream cylinders (see Cases II-IV). Due to the flow symmetry, the dynamic response of cylinders in pairs "c1"-"c2", "c3"-"c4" and "c5"-"c6" is similar but in 
opposite direction, it coincides with findings in [12]. The vibration is dominant in the lift direction of cylinders "c5" and "c6", except for Case IV.

The seven-cylinder cluster configuration (Case VII) can be considered the unit that has been proposed to model a fully flexible rod bundle. As in all preview cases, flexible cylinder trajectory orbits are elliptic. The wake effect of "c3" and "c4" is strongly expressed if we compare Case VI and Case VII with Case III.
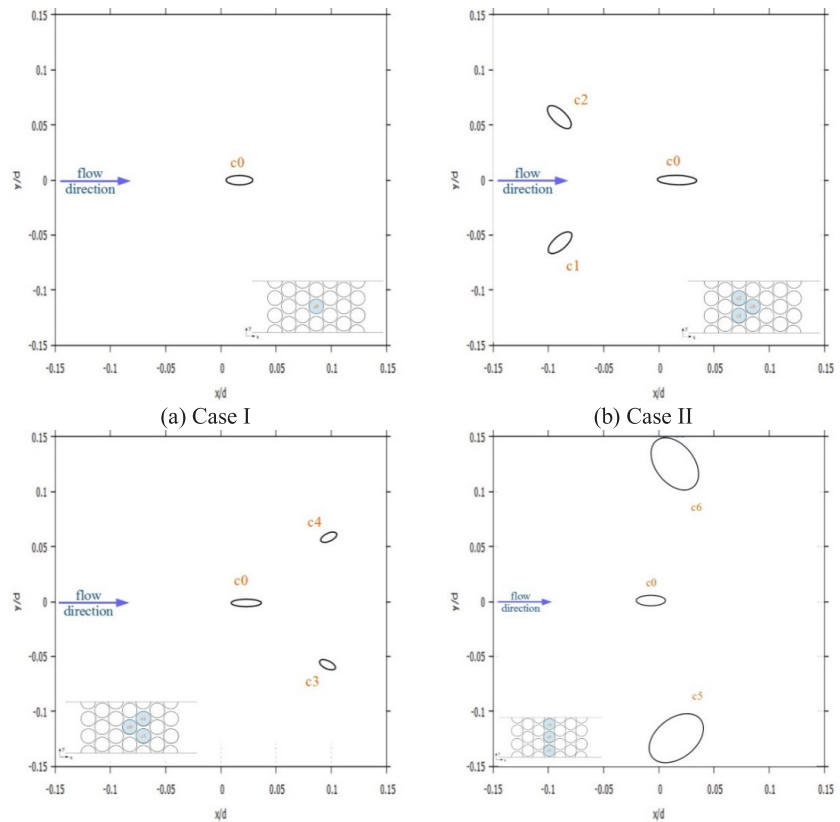

(c) Case III

(d) Case IV

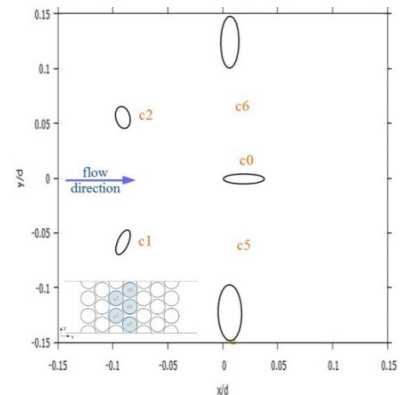

(e) Case V
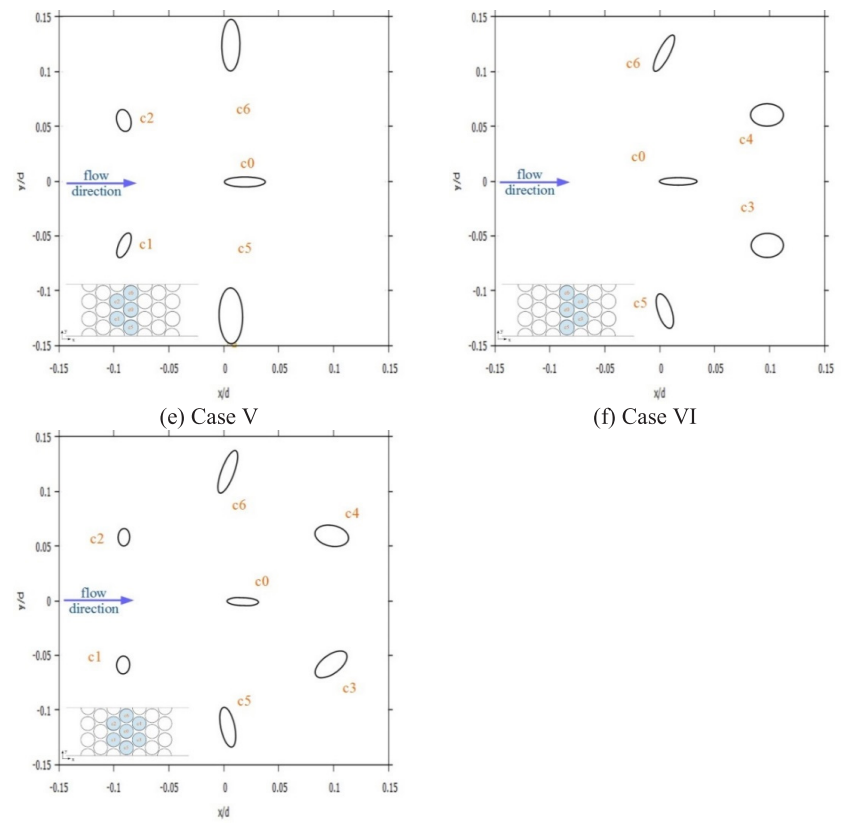

(f) Case VI

(g) Case VII

Fig. 4. The vibration orbits of flexibly-mounted cylinders. Displacements in $\mathrm{x}$ and $\mathrm{y}$-direction are divided by cylinder diameter. 
The oscillation frequencies, $\mathrm{f}_{\text {oscil }}$ of the central cylinder " $\mathrm{c} 0$ " for all cases are summarised in Table 4. The frequency of "c0" is similar in Case I and Case VI, where upstream and downstream cylinders are not flexibly-mounted. The frequency of "c0" increases if the movement of cylinders "c1" to "c4" is allowed.

Table 4

The Oscillation Frequencies of Central Cylinder

\begin{tabular}{|l|c|c|c|c|c|c|}
\hline \multirow{2}{*}{} & \multicolumn{6}{|c|}{ Cases } \\
\cline { 2 - 7 } & Case I & Case II & Case III & Case VI & Case V & Case VII \\
\hline$f_{\text {oscil }}$ & $69.63 \mathrm{~Hz}$ & $83.87 \mathrm{~Hz}$ & $80.25 \mathrm{~Hz}$ & $68.72 \mathrm{~Hz}$ & $91.63 \mathrm{~Hz}$ & $80.25 \mathrm{~Hz}$ \\
\hline
\end{tabular}

Simulation results show that in cases when upstream cylinders are flexible (Case II and Case V), the oscillation frequency of central cylinder increases if compared with cases where downstream cylinders vibrate.

\section{CONCLUSIONS}

The flow-induced vibrations have been predicted using numerical simulations of water flow through groups of flexibly-mounted cylinders in otherwise rigid rod array of the triangular arrangement. To model turbulence, the RNG k-epsilon turbulence model has been used. For validation of CFD results, the simulations of the rigid cylinder array and calculated pressure drop comparison with experimental results have been made. The quasi-static results have been applied as initial conditions for transient simulations.

The single flexibly-mounted cylinder in the rigid array, as well as six groups with three, five or seven flexible cylinders have been studied to find the major tendencies in the closed-packed tube bundle related to the flow-induced vibrations.

The interaction between the fluid and the solid rods in a triangular rod bundle has been modelled using a six degree-of-freedoms solver. In the case when upstream or downstream cylinders are flexibly mounted, the central cylinder becomes more unstable.

There are no significant differences in the oscillation frequency of central cylinder observed comparing the case of the single flexibly-mounted cylinder with the case where upper and lower cylinders are flexible.

\section{REFERENCES}

1. Vincent, B.T., Hassan, M.A., \& Rogers, R.J. (2009). A probabilistic assessment technique applied to a cracked heat exchanger tube subjected to flow-induced vibration. Journal of Pressure Vessel Technology, 131, 031305-1-6. DOI: 10.1115/1.3109989

2. Weaver, D.S., \& Fitzpatrick, J.A. (1988). A review of cross-flow induced vibrations in heat exchanger tube arrays. Journal of Fluids and Structures, 2, 73-93. DOI: 10.1016/ S0889-9746(88)90137-5

3. Khalifa, A., Weaver, D., \& Ziada, S. (2012). A single flexible tube in a rigid array as a model for fluidelastic instability in tube bundles. Journal of Fluids and Structures, 34, 14-32. DOI: 10.1016/j.jfluidstructs.2012.06.007 
4. de Pedro, B., Parrondo, J., Meskell, C., \& Oro, J. F. (2016). CFD modelling of the crossflow through normal triangular tube arrays with one tube undergoing forced vibrations or fluidelastic instability. Journal of Fluids and Structures, 64, 67-86. DOI: 10.1016/j. jfluidstructs.2016.04.006

5. Charreton, C., Béguin, C., Yu, K.R., \& Étienne, S. (2015). Effect of Reynolds number on the stability of a single flexible tube predicted by the quasi-steady model in tube bundles. Journal of Fluids and Structures, 56, 107-123. DOI: 10.1016/j.jfluidstructs.2015.05.004

6. Mahon, J., \& Meskell. C. (2013). Estimation of the time delay associated with damping controlled fluidelastic instability in a normal triangular tube array. Journal of Pressure Vessel Technology, 135, 030903-1-7. DOI: 10.1115/1.4024144

7. Price, S.J. (1995). A review of theoretical models for fluidelastic instability of cylinder arrays in cross-flow. Journal of Fluids and Structures, 9, 463-518. DOI: 10.1006/ jfls. 1995.1028

8. Andjelić, M., Austermann, R., \& Popp, K. (1992). Multiple stability boundaries of tubes in a normal triangular cylinder array. Journal of Pressure Vessel Technology, 114, 336 343. DOI: $10.1115 / 1.2929049$

9. Khalvatti, A., Mureithi, N.W., \& Pettigrew, M.J. (2010). Effect of preferential flexibility direction on fluidelastic instability of a rotated triangular tube bundle. Journal of Pressure Vessel Technology, 132, 041309-1-14. DOI: 10.1115/1.4002181

10. Hassan, M., Gerber, A., \& Omar, H. (2010). Numerical estimation of fluidelastic instability in tube arrays. Journal of Pressure Vessel Technology, 132, 041307-1-11. DOI: $10.1115 / 1.4002112$

11. Ibrahim, R.A. (2011). Mechanics of pipes conveying fluids - Part II: Applications and fluidelastic problems. Journal of Pressure Vessel Technology, 133, 024001-1-30. DOI: $10.1115 / 1.4001270$

12. Jafari, H.H., \& Dehkordi, B.G. (2013). Numerical prediction of fluid-elastic instability in normal triangular tube bundles with multiple flexible circular cylinders. Journal of Pressure Vessel Technology, 135, 031102-1-14. DOI: 10.1115/1.4023298

13. Holzmann, T. (2017). Mathematics, numerics, derivations and OpenFOAM (4th ed.). Leoben: Holzmann CFD.

14. Kim, S.N., \& Jung, S.Y. (2000). Critical velocity of fluidelastic vibration in a nuclear fuel bundle. Korean Society of Mechanical Engineers International Journal, 14(8), 816-822.

15. Weaver, D.S., \& El-Kashlan, M. (1981). On the number of tube rows required to study cross-flow induced vibrations in tube banks. Journal of Sound and Vibration, 75(2), 265273. DOI: $10.1016 / 0022-460 X(81) 90344-8$.

16. Upnere, S., Jekabsons, N., \& Dementjevs, S. (2016). Analysis of cross-flow induced vibrations in staggered arrangement of multi-cylinder system. In 5th European Seminar on Computing, 5-10 June 2016 (pp. 225). Pilsen, Czech Republic.

17. Lam, K., Jiang, G.D., Liu, Y., \& So, R.M.C. (2006). Simulation of cross-flow-induced vibration of cylinder arrays by surface vorticity method. Journal of Fluids and Structures, 22, 1113-1131. DOI: 10.1016/j.jfluidstructs.2006.03.004 


\section{SKAITLISKS PĒTİJUMS PAR PLŪSMAS IZRAISĪTĀM VIBRĀCIJĀM \\ TRĪSSTŪRVEIDA MASĪVĀ AR VAIRĀKIEM ELASTİGI \\ NOSTIPRINĀTIEM CILINDRIEM}

\section{S. Upnere}

Kopsavilkums

Stieņi un caurules siltummaiņos, tvaika ǵeneratoros vai kodolspēkstaciju degvielas stieṇos tiek pakḷauti plūsmas izraisītām vibrācijām. Ja stieṇa svārstību amplitūda pārsniedz kritisko vērtību, tad var rasties bojājumi sistēmā. Neplānota iekārtu slēgšana atsevišķos gadījumos var radīt ievērojamus finansiālus zaudējumus vai vides piesārṇojumu, tādēl ir svarīgi novērtêt potenciālās problēmas jau sistēmas izstrādes posmā.

Aprakstītais darbs ir saistīts ar vairāku elastīgi nostiprinātu stieņu uzvedību plūsmas ietekmē daudzstieṇu sistēmā. Tiek analizētas sešu dažādu oscilējošo stieṇu grupu uzvedības tendences šķērsplūsmā. Tiek novērtēta blakus esošo cilindru ietekme uz centrālā cilindra svārstību īpašībām. Atvērtā koda skaitliskās hidrodinamikas programmatūra tiek izmantota, lai aprēķinātu šķidruma plūsmu kanālā, kas satur masīvu ar septin̄ām cilindru rindām. Iegūtie rezultāti tiek salīdzināti ar literatūrā pieejamiem skaitliskiem rezultātiem.

24.07.2018. 